\title{
PHYSICO-CHEMICAL TRANSFORMATIONS DURING THERMAL TREATMENT OF PHOSPHORITES AND SOLUBILITY OF THE PRODUCTS
}

\author{
TIIT KALJUVEE, REIN KUUSIK and MIHKEL VEIDERMA \\ Department of Basic and Applied Chemistry \\ Tallinn Technical University \\ Ehitajate tee 5, Tallinn 19086
}

\begin{abstract}
A comparative investigation of physico-chemical transformations taking place during heating up to $1300^{\circ} \mathrm{C}$ of calcareous and silico-calcareous phosphorites of different deposits (Kazakhstan, Russia, Uzbekistan, Israel, Estonia), and of the influence of thermal treatment on the solubility of products in processing by sulphuric and/or phosphoric acids was carried out by means of chemical, thermal, SEM, X-ray diffraction, IR spectroscopy and other methods of analysis.
\end{abstract}

\section{INTRODUCTION}

One of the possibilities of benefication of low quality phosphorites, particularly carbonaceous and silico-carbonaceous as well as high-level organic matter or pyrite containing phosphorites is their thermal treatment. For operating the thermal processing of phosphorites in optimum conditions, it is important to establish the transformations taking place during thermal treatment of phosphorites and their influence on the quality of the products.

The aim of our work was to establish optimum conditions for thermal treatment of the phosphorites studied, i. e. conditions which would guarantee the preservation of $\mathrm{Ca}$ and $\mathrm{Mg}$ oxides formed during decomposition of carbonates in the free form for the following removal of them ${ }^{1}$, and to avoid the decrease in the solubility of apatite mineral and the increase in the solubility of accompanying minerals during acidic processing of the products. In this paper the results of studying the influence of thermal treatment on the solubility of phosphorites in the phosphoric acid are presented.

\section{CHARACTERIZATION OF SAMPLES}

Samples of phosphorites from different deposits were studied: Kokdzhon, Heres, Dzhanatas (Kazakhstan), Dzheroi-Sardara (Uzbekistan), Yegorjevsk, Kingisepp 
(Russia), Nahal-Zin (Israel), Toolse, Kabala (Estonia). The solubility tests in phosphoric acid were carried out with the first six samples. The chemical composition of these samples is presented in the Table. The main constituent of the samples is fluorcarbonateapatite, the main accompanying minerals are dolomite, calcite, pyrite, quartz, organic matter, etc. The content of apatite as well as the impurities varied in a large range - the content of $\mathrm{P}_{2} \mathrm{O}_{5}$ from $16.9 \%$ (Heres) to $27.2 \%$ (Kingisepp), $\mathrm{SiO}_{2}$ from $4.1 \%$ (Yegorjevsk) to $18.4 \%$ (Heres), etc. (Table).

In the solubility tests phosphoric acid of reactive grade quality, diluted to $20 \%$ of $\mathrm{P}_{2} \mathrm{O}_{5}$ was used.

TABLE.

CHEMICAL COMPOSITION OF THE SAMPLES

\begin{tabular}{|l|c|c|c|c|c|c|}
\hline $\begin{array}{l}\text { Content, \% } \\
\text { by mass }\end{array}$ & $\begin{array}{c}\text { Kok- } \\
\text { dzhon }\end{array}$ & $\begin{array}{c}\text { Dzha- } \\
\text { natas }\end{array}$ & Heres & $\begin{array}{c}\text { Yegor- } \\
\text { jevsk }\end{array}$ & $\begin{array}{c}\text { Dzheroi- } \\
\text { Sardara }\end{array}$ & $\begin{array}{c}\text { Kingi- } \\
\text { sepp }\end{array}$ \\
\hline $\mathrm{P}_{2} \mathrm{O}_{5}$ & 22.7 & 25.2 & 16.9 & 29.2 & 22.2 & 27.2 \\
$\mathrm{CaO}$ & 40.0 & 42.1 & 38.0 & 47.2 & 45.5 & 43.5 \\
$\mathrm{MgO}$ & 4.1 & 4.0 & 8.2 & 1.5 & 0.7 & 3.1 \\
$\mathrm{Al}_{2} \mathrm{O}_{3}$ & 1.2 & 0.7 & 0.7 & 1.0 & 2.5 & 0.2 \\
$\mathrm{Fe}_{2} \mathrm{O}_{3}$ & 1.1 & 1.2 & 0.9 & 2.3 & 0.8 & 1.2 \\
$\mathrm{CO}_{2}$ & 9.7 & 7.9 & 18.4 & 6.1 & 9.2 & 8.3 \\
$\mathrm{Corg}_{\text {org }}$ & 0.15 & - & 0.18 & 0.87 & 0.98 & 0.30 \\
$\mathrm{SiO}_{2}$ & 12.8 & 11.7 & 10.7 & 4.1 & 7.5 & 17.4 \\
$\mathrm{SO}_{3}$ & 1.2 & 0.7 & 1.0 & 1.4 & 0.1 & 2.0 \\
$\mathrm{~S}^{2-}$ & 0.18 & 0.18 & 0.16 & 0.57 & 0.05 & 0.53 \\
$\mathrm{~F}$ & 2.7 & 2.4 & 1.2 & 4.2 & 2.9 & 3.2 \\
\hline
\end{tabular}

\section{METHODS AND EXPERIMENTAL}

Thermal analysis with the simultaneous registration of TG, DTG, DTA and TGT curves was carried out in a Q-Derivatograph (MOM,Hungary) in the stream of oxygen or helium (10 $\mathrm{dm}^{3}$ per hour) with absorption of evolved gases and titration of the solution at $\mathrm{pH}=4.0$ or 9.3 for determination of $\mathrm{SO}_{2}$ or $\mathrm{CO}_{2}$ in the evolved gases. ${ }^{2,3}$ The heating rate was $5 \mathrm{~K}$ per min and the mass of samples $300-350 \mathrm{mg}$.

Thermal treatment of the samples for determination of their solubility in the phosporic acid was carried out in a laboratory tube furnace in a Pt-crucible at $900^{\circ}$, $1000^{\circ}, 1100^{\circ}$ during 15 minutes and at $1200^{\circ} \mathrm{C}$ during 2 hours in the stream of air. The 
samples obtained as well as initial samples of phosphorites were treated with $\mathrm{H}_{3} \mathrm{PO}_{4}$ (mass ratio solid : liquid $=1: 2.5$ ) in a water basin at $75^{\circ} \mathrm{C}$ during one hour, filtered and washed. The insoluble in $\mathrm{H}_{3} \mathrm{PO}_{4}$ residue was treated with a $5 \%$-solution of $\mathrm{Na}_{2} \mathrm{CO}_{3}$ for removal of silicon acid, filtered, the filtrates and washing waters were then connected and the content of $\mathrm{P}_{2} \mathrm{O}_{5}$ and $\mathrm{SiO}_{2}$ (soluble in phosphoric acid $\mathrm{SiO}_{2}$ ) in the obtained solution was determined. The solid residue after these procedures was heated to $1000^{\circ} \mathrm{C}$ (was fixed the content of quartz+insoluble silicates), and treated with HF-acid for determination of the total content of insoluble in phosphoric acid oxides: $\mathrm{Me}_{2} \mathrm{O}_{3}+$ $\mathrm{MeO}+\mathrm{Me}_{2} \mathrm{O}$ (Me - cation).

\section{RESULTS AND DISCUSSION}

Based on the results of complex thermal analysis of the samples it was established that emission of $\mathrm{CO}_{2}$ started at $200^{\circ} \mathrm{C}$ and continued up to $1250-1300^{\circ} \mathrm{C}$, originating from the oxidation of organic carbon, decomposition of siderite, dolomite and calcite and rearrangements in the apatite structure. Emission of $\mathrm{SO}_{2}$ which started at $400-450^{\circ} \mathrm{C}$ and proceeded up to $1250-1300^{\circ} \mathrm{C}$, originated from the oxidation of pyrite and organic sulphur and from the sulphates.

A great influence of the temperature of thermal treatment of phosphorites on the composition and physico-chemical properties, especially on the solubility in $\mathrm{H}_{3} \mathrm{PO}_{4}$ of the silica-containing part of phosphorite was observed. The total content of soluble $\mathrm{SiO}_{2}$ in Yegorjevsk phosphorite increased from $0.85 \%$ in initial sample to $3.95 \%$ in the sample thermally treated at $1200^{\circ} \mathrm{C}$ or from $20.7 \%$ to $96.3 \%$ of the total content of $\mathrm{SiO}_{2}$ in the sample (FIGURE 1). The same values for Kokdzhon phosphorite increased from $4.2 \%$ to $12.3 \%$ or, relatively, from $32.5 \%$ to $96.0 \%$ of the total $\mathrm{SiO}_{2}$ content. So, the relative content of soluble $\mathrm{SiO}_{2}$ which varies in initial samples in the range of $15-16 \%$ (Dzhanatas, Heres) to $40 \%$ (Dzheroi-Sardara) increased during thermal treatment at $900^{\circ} \mathrm{C}$ up to $25-65 \%$ and at $1100-1200^{\circ} \mathrm{C}$ up to $95-99 \%$ as calculated from the total content of $\mathrm{SiO}_{2}$ in phosphorites. Exception to the phosphorites studied was Kingisepp, solubility of the silica part of which increased only from $6 \%$ in the initial sample to $35 \%$ of the total content of $\mathrm{SiO}_{2}$ in the sample treated at $1200^{\circ} \mathrm{C}$.

As a result, the insoluble part of silica in the phosphorite samples thermally treated decreased and in the samples heated at $1100-1200^{\circ} \mathrm{C}$ it was only $0.2-0.5 \%$, except for Kingisepp phosphorite in which it was 7.5\% (FIGURE 2A). By X-ray data the $\mathrm{SiO}_{2}$ in the initial sample of Kingisepp phosphorite is presented mainly as wellcristallined quartz, in the other phosphorites besides not well-cristallined quartz also as 
wollastonite and, possibly, as albite or microcline.

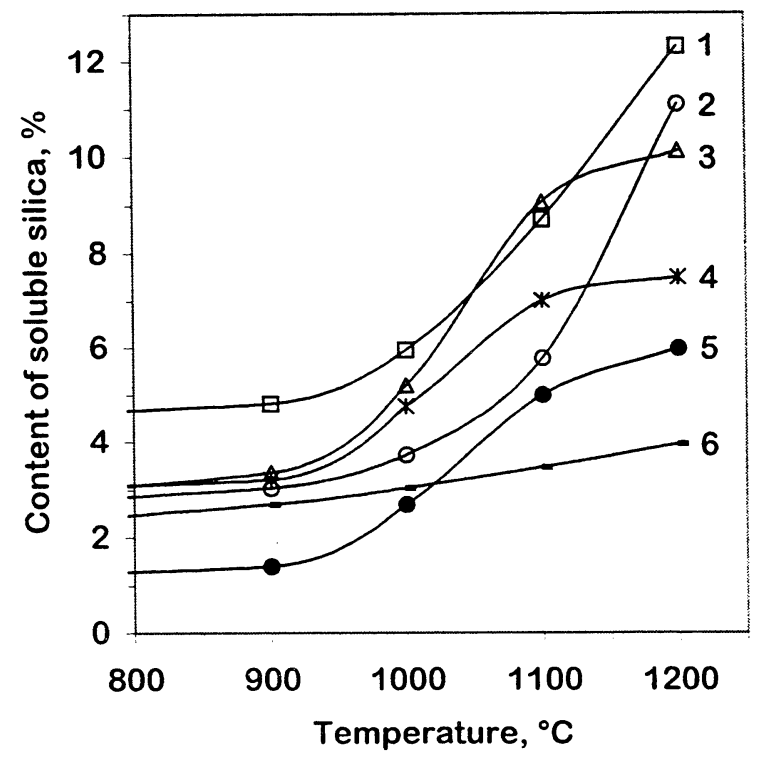

FIGURE 1. Influence of temperature of thermal treatment of samples on the solubility of silica in the phosphoric acid: 1 - Kokdzhon, 2 - Dzhanatas, 3 -Heres, 4 - Dzheroi-Sardara, 5 -Kingisepp, 6 - Yegorjevsk.

During heating of phosphorites great changes took part in the composition of insoluble part of phosphorite as well, and they were different for different phosphorites. A poor increase in the content of insoluble oxides was observed in Kokdzhon and Heres phosphorites and about 1.5 times increase (from 1.8 to $2.7 \%$ ) in Dzhanatas phosphorite heated at $900-1000^{\circ} \mathrm{C}$ and a poor decrease of it in Yegorjevsk and Dzheroi-Sardara phosphorites at these temperatures (FIGURE 2B). The following increase in the temperature resulted in rapid decrease in the content of insoluble oxides in Kokdzhon (from $4.1 \%$ to $0.38 \%$ ), Dzhanatas (from $2.7 \%$ to $1.3 \%$ ) and Dzheroi-Sardara phosphorites (from $2.5 \%$ to $0.61 \%$ ). In Heres phosphorite the content of insoluble oxsides also decreased, but it stopped and stayed nearly constant at 1100$1200^{\circ} \mathrm{C}$ on the level of $1.7 \%$. Only in Kingisepp phosphorite the increase in temperature was followed by the increase in the content of insoluble oxides - from $1.5 \%$ in the initial sample to $4.8 \%$ in the sample heated at $1200^{\circ} \mathrm{C}$.

So, the relative content of insoluble in $\mathrm{H}_{3} \mathrm{PO}_{4}$ oxides in insoluble part of phosphorites (quartz +insoluble silicates) increased from $13.5-35.0 \%$ in initial sample to 

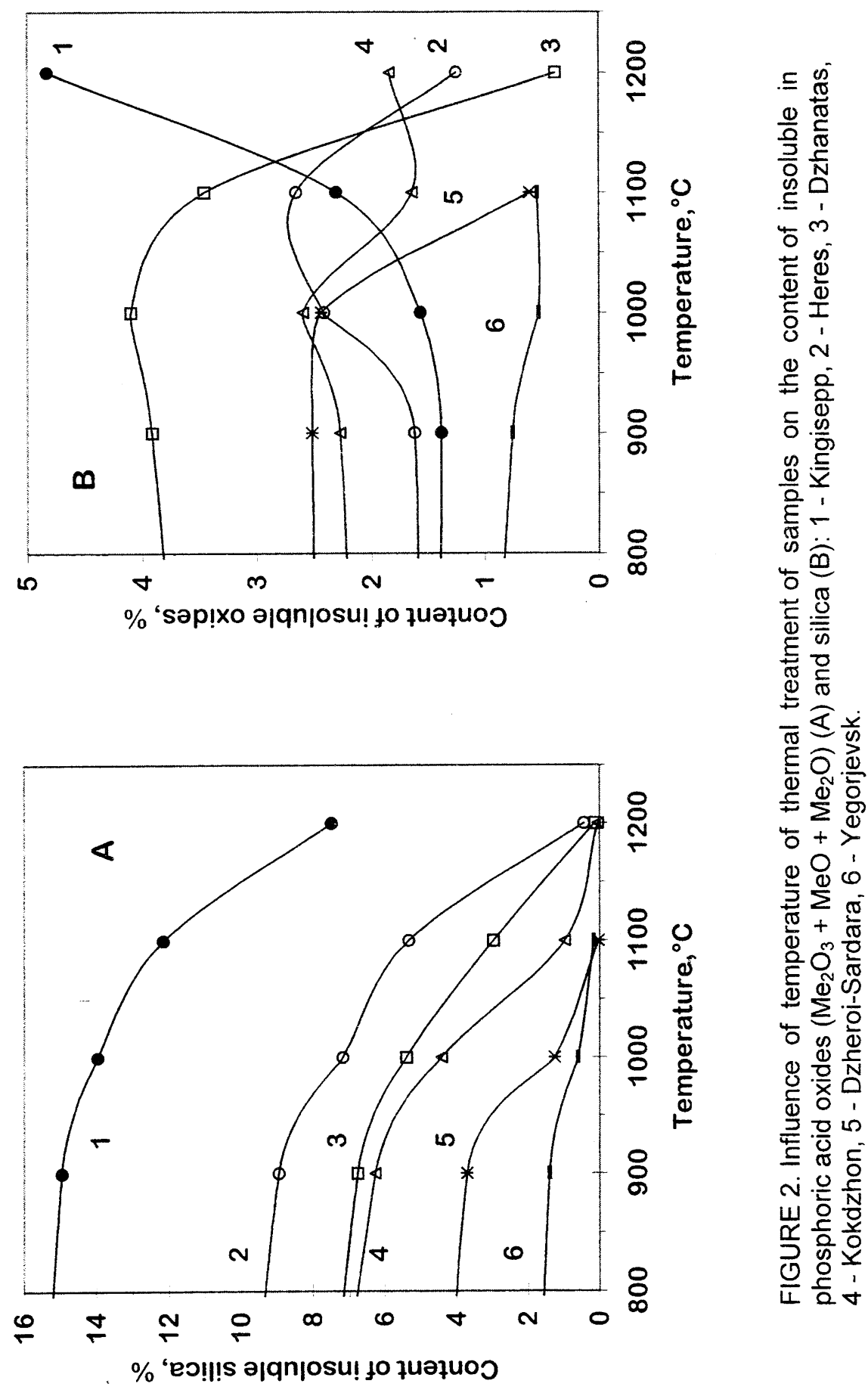
$73.9-76.9 \%$ of Kokdzhon, Dzhanatas and Yegorjevsk phosphorites heated at $1200^{\circ} \mathrm{C}$ and from $16.3-31.5 \%$ to $96-97 \%$ in Heres and Dzheroi-Sardara phosphorites. In Kingisepp phosphorite the content of insoluble oxides increased from $8.4 \%$ in initial sample to $39.2 \%$ in thermally treated at $1200^{\circ} \mathrm{C}$ sample.

These changes in the solubility of $\mathrm{SiO}_{2}$ and in the composition of insoluble part of phosphorites correlated well with the results of $X$-ray analysis of the samples. The $X$ ray data indicated that at higher temperatures (over $900^{\circ} \mathrm{C}$ ) an interaction between silica part of phosphorites and $\mathrm{Ca}$ and $\mathrm{Mg}$ oxides formed during the decomposition of carbonates takes place. At $1100-1200^{\circ}$ in the thermally treated samples, in addition to apatite mineral and to a little content of diopside the presence of akermanite, brownmillerite and merwinite which all are well-soluble in phosphoric acid was determined. The X-ray data confirmed that besides of apatite mineral the sample of Kingisepp phosphorite heated at $1200^{\circ} \mathrm{C}$ contained quartz and diopside which are both hardly-soluble in phosphoric acid.

\section{CONCLUSIONS}

An increase in the solubility of silica with increasing the temperature of thermal treatment of phosphorites was observed. Consequently, $\mathrm{Ca}$ and $\mathrm{Mg}$ oxides formed as well as other metal oxides contained in phosphorites react with the silica part of phosphorites. At that the formation of well-soluble in phosphoric acid compounds as akermanite, brownmillerite, merwinite takes place. Only the sample of thermally treated Kingisepp phosphorite contained a high amount of unreacted quartz and newly formed mineral - diopside, both hardly-soluble in phosphoric acid.

So, the optimum thermal treatment temperature of the studied phosphorites for the following extraction of phosphoric acid seems to be $850-900^{\circ} \mathrm{C}$. Below $850^{\circ} \mathrm{C}$ decomposition of carbonates is not complete. The use of higher temperatures is accompanied by an increase in the solubility of silicates and the other secondary compounds which leads to technological complications in the manufacturing of phosphoric acid and to contamination of products based on the use of $\mathrm{H}_{3} \mathrm{PO}_{4}$. The solubility of apatite mineral was in the range of $95-99 \%$ of the total content of $\mathrm{P}_{2} \mathrm{O}_{5}$ in the initial samples.

\section{REFERENCES}

1 T. Kaljuvee, R. Kuusik and M. Veiderma, Int. J. Miner. Process. 43, 113 (1995).

2 J. Paulik, F. Paulik and M. Arnold, J. Therm. Anal., 25, 327 (1982).

3 F. Paulik, J. Paulik and M. Arnold, J. Therm. Anal., 29, 333 (1984). 